\title{
Setting Health-Care Priorities: A Reply to Massimo Reichlin
}

\author{
- Torbjörn Tännsjö -
}

\begin{abstract}
This is a short reply to Professor Reichlin's comment on my book Setting Health-Care Priorities. What Ethical Theories Tell Us. The version of prioritarianism I rely on in the book is defended as the most plausible one. The general claim that there is convergence between all plausible theories on distributive justice is also defended with regard to assisted reproduction, disability, and enhancement. Keywords: priority setting, prioritarianism, assisted reproduction, disability, enhancement.
\end{abstract}

Published online: 27 December 2021

\section{Introduction}

I am grateful for having been offered the opportunity to respond to Professor Reichlin's comments on my book. ${ }^{1}$ His comments are directed primarily at the theoretical part of the book, where I claim that there are three mutually inconsistent theories of distributive justice that are all at least defensible. He also questions my claim that there is convergence in the actual world, when we apply the theories (CONVERGENCE). He doesn't discuss my claim that we will not abide by them (FUTILITY). Nor does he discuss my claim that, even if we do not abide by the theories, they remain plausible candidates for a correct theory of distributive justice. Here I will devote a few words to the theoretical disagreement and then comment on CONVERGENCE.

\section{Theoretical disagreement}

When I read the reply from Professor Reichlin, I was reminded of the Guatemalan-American philosopher Héctor-Neri Castaneda, who famously said, "When in doubt, complicate." Reichlin gives a correct account of the main distributive theories I discuss and find defensible: the maximin/leximin-theory, egalitarianism, and utilitarianism, with or without a prioritarian amendment. I think of them as complete moral theories. This is also true of the plethora of possible prioritarian amendments to utilitarianism, urging us to maximize a weighted sum of happiness, where the choice of a moral weight is based on the idea that unhappiness (at a moment) has an increasing moral importance. On

\footnotetext{
Torbjörn Tännsjö

Department of Philosophy

Stockholm University

10691 Stockholm, Sweden

e-mail: torbjorn.tannso@philosophy.su.se

${ }^{1}$ Reichlin (2021)
} 
my understanding of the situation, even if all these theories are defensible, at most only one of them can be correct (since they are inconsistent with one another). If I understand Reichlin correctly, he accepts all of them (making an exception for prioritarianism as characterized by myself). Instead of my form of prioritarianism he adds another one. A problem with such an ecumenical view, of course, is that it doesn't provide us with moral guidance in particular cases. When confronted with conflicting pro tanto or prima facie reasons for action, we still want to know, absolutely speaking, what we ought to do. To find this out, we have to rely on the situation, our intuition, or something of the sort. Reichlin is not explicit on this point.

Why does he not also accept prioritarianism as it has been characterized by myself? Why does he want to "replace" it with his own favorite idea of prioritarianism? Given his stance, where he assumes that moral principles provide merely pro tanto reasons for action, why does he not accept my favored understanding of prioritarianism as well? The explanation seems to be that he finds his "interpretation" of the view more fruitful. This way of describing matters is confusing. There is no such thing as a correct understanding of "prioritarianism." What I discuss is one basic moral theory (or, rather, a family of theories until we have fixed the moral priority weights), while he prefers another one. I can't help feeling that the one I discuss presents us with more of a moral challenge.

In what manner, therefore, does his prioritarianism differ from my own? If I understand him correctly, it is mainly in two respects. His theory is silent in some cases where mine provides us with moral guidance. His theory is silent in intrapersonal cases. Moreover, his theory has nothing to say about whether a life is worth living or not. Otherwise, it is equivalent to my version.

So, how do we decide cases where his theory is silent? We are here recommended to consider some other theory (such as utilitarianism), but why not my favored form of prioritarianism as well?

Think of the following case. We have two persons competing for the only available medical resource. One of them has led an extremely happy life up to this moment but now she is in a desperate situation. It is possible to prolong her life by one additional year but there will be ups and downs during this additional year. Given the priority weights suggested by my favored prioritarian view, because of the extra moral weights attached to its downs, this additional year is not worth living (it is worth not living), even though it contains a net surplus of happiness over unhappiness. This patient competes for the available resources with a person who has up to now lived an unhappy life (her life has gone on for a long time and mostly just below the level where life is better not to experience). She happens to be extremely happy just now and the available resource could make her even a little bit happier. To whom should the available resource go?

The utilitarian verdict: we should tend to the patient in the desperate situation. We assume that the additional net surplus in her additional year is larger than the possible gain for the person who is extremely happy right now (but who has led an unhappy life on the whole).

The egalitarian verdict: to the extremely happy person, since she has led such a miserable life on the whole (this is what I have called the insensitivity to suffering exhibited by egalitarianism). 
The prioritarian verdict (on my understanding of prioritarianism): to the extremely happy individual. If it was possible, we should benefit the person in the desperate situation, but to add one year to her life means no benefit to her; on the contrary, it means harming her.

Reichlin's verdict: this is not easy to find out.

Had it not been for the fact that egalitarianism favored the happy individual (because of the accumulated unhappiness in her life, which is my addition to the example), he would have opted for the person in the desperate situation (we are told). But this not only means that he here relies on the silence on his favored "interpretation" of prioritarianism, but on the tacit assumption that the version of prioritarianism I discuss is false. It is rejected even as a prima facie or pro tanto principle. Otherwise, it should also have a voice in the chorus sung by all the theories providing prima facie or pro tanto reasons for actions. Since I find prioritarianism as understood by me (a complete moral theory) quite attractive (even if, in the final analysis, I opt for utilitarianism), I find this move strange. If you can live with all the other theories, why not live with my version of prioritarianism as well? A comparison with Dennis McKerlie is perhaps apt here. He accepts both egalitarianism, applied to entire lives, egalitarianism applied to moments, as well as the kind of prioritarianism I have discussed. They are all taken to provide us with plausible prima facie or pro tanto reasons for action. ${ }^{2}$

So, what should be done, according to Reichlin? I suppose that comes down to an intuitive judgement to be made in concrete situations. But since what I have presented is an abstract thought experiment, I suppose no definite answer can be provided by him.

\section{Disagreement about CONVERGENCE}

I get the impression that, on the whole, Professor Reichlin and I agree on CONVERGENCE. On all plausible theories, more resources should be directed from marginal life extension to the care and treatment of people suffering from mental illness. However, on three counts he disagrees: assisted reproduction, treatment of chronical illness (and disability) and enhancement. Here utilitarian and egalitarian thought come apart, he argues.

Professor Reichlin correctly observes that while utilitarianism (with or without a prioritarian amendment of the kind I discuss) favors the creation of more happy sentient life (up to the point where it is not sustainable in the long run), maximin/leximin and egalitarian thought is based on the notion of the separateness of people and they take a person-affecting form. However, of note is the fact that these theories permit the repugnant conclusion and, once we have reached it, the actual people in the Z-world are happy to be around. If we had not created them, we would have wronged them (this normative variance on what we do is a problematic aspect the person-affecting theories in general). And people like to have children. When we give them the opportunity to satisfy their desire, we meet an important need they have, we allow them to create new happy tax-payers, and once there, these taxpayers are (in general) happy to be around. This means that there are also good reasons for subsidising assisted reproduction on

\footnotetext{
${ }^{2}$ McKerlie (2013).
} 
egalitarian grounds. Remember that the need for marginal life extension also carries even less weight from the point of view of these theories that they carry from a forward-looking utilitarian point of view.

What about chronic disease and disability? I assume that Professor Reichlin has read what I say about this in my book, but he doesn't comment on it. Instead he shares with us his own speculation:

Imagine two patients suffering from the same medical condition, who can receive the same benefit from the available treatment; assume that the only difference between them is that one is otherwise healthy, and the other suffers from a chronic disease (say, Down's syndrome, diabetes or paraplegia). In such a case, utilitarianism would prioritize treating the former, since this would guarantee an increase in expected life years from 0.8 to 1 QALY, while treating the other for the same condition would guarantee an increase, say, from 0.5 to 0.7 QALY per year. If we multiply this value by the number of years the two patients are expected to live, assuming that they are equal, the total sum of QALY saved by treating the chronically ill or disabled individual will be less.

This is odd. What is intended is perhaps that each patient gains, if treated, 0.2 in quality of life. But then the utilitarian would be indifferent between the two patients. A related example is one where only one life can be saved. Then utilitarianism favors the otherwise healthy patient over the disabled one. But is that counterintuitive?

We should bear in mind that people can adapt to many disabilities, such as paraplegia. And Down's syndrome is not likely to compromise the quality of the life of a person with the condition. However, if we speak of some condition that really lowers the quality of life, such as chronic pain or depression, it does seem to be reasonable, if we have to make a choice, to save the life of the happy person rather than the miserable one.

Finally, what about enhancement? Of course, mood enhancement is of direct utilitarian (hedonistic) importance, but since it will probably be easier to enhance the mood of people who are unhappy (depressed) than to enhance the mood among people who are already quite happy, those who are unhappy (depressed) will also have an edge when matters are assessed from a utilitarian point of view. Moreover, in a just welfare state, the gains made from cognitive enhancement will be reaped by all.

\section{References}

McKerlie D. (2013), Justice Between the Young and the Old, Oxford University Press, Oxford. Reichlin M. (2021), "Prioritarianism in Health-Care: Resisting the Reduction to Utilitarianism," Diametros 18 (69): 20-32. 